\title{
The Dilemma of the Artist in Contemporary British Theatre: A Theoretical Background
}

\author{
By Majeed Mohammed Midhin* \\ Clare Finburgh ${ }^{+}$
}

The present paper tackles the dilemma of the artist in contemporary British theatre. It commences by introducing a clear-cut definition of the dilemma of the artist in literature.There are certainly many dilemmas for the artist. One of the most painful is social: How can the artist function as a member of a certain community and, at the same time, retain the distinctiveness of his/her role as an outsider whose social usefulness is based on his/her chronic estrangement from the ordinary concerns of society?; by this, I mean the perplexing dilemma in which the artist finds in his/her struggle to reconcile private desire to public expectation. A second dilemma of the artist is economic: How can artists practice their art? This dilemma has two facets. On the one hand it is related to subsidy the art received from public budget. On the other, it is the materialistic norms of the society in which the artist has immersed himself/herself. Indeed, the dilemma that faces radical artists nowadays is that the popular forms of communication are often controlled by conventional and commercial forces at work in society. However, it is not only money which is the source of the artist's economic dilemma, but rather the existence or the paucity of good audiences. Under such perilous circumstances, the artist's genuine dilemma lies in confronting the Zeitgeist, the general intellectual and moral tendencies of an era, which can be evasive and intangible. According to the above premises, three points will be discussed.

1. The function of the artist and art in society. This will be investigated according to those radical thinkers such as Lukacs, Brecht, Benjamin, Gramsci, Shklovsky and Sartre. It also sheds light on Howard Barker's views of theatre.

2. Art and Commitment. The concept of commitment will be discussed to draw a complete picture of how artists and thinkers responded to it. Accordingly, the cult of "Art for art's sake" in opposition to art for other aims, will be highlighted. No doubt, the idea of commitment forms a crucial component in literature.

3. Art and Politics. It traces the general similarity between the intentions of art and politics. Both are an attempt to give coherence and form to the disorder of experience. However, the nature and function of art implies the inevitable political involvement to a certain degree, on the part of the writer. Sometimes, art is exploited for political propaganda and ideologies.

Keywords: Dilemma, Zeitgeist, Commitment, Art for Art's Sake, Political Theatre

${ }^{*} \mathrm{PhD}$ Candidate, University of Essex, UK and University of Anbar, Iraq.

${ }^{\dagger} \mathrm{PhD}$ in English Literature, University of Essex, UK. 


\section{Theoretical Background of the Dilemma of the Artist in Literature}

It has been maintained by Bertha (2009, p.347) that the central place an artist occupies within a work of art gives an additional dimension to plays, since the fictional artist's point of view, attitudes to the world and evaluation of phenomena may double or multiply the layers of the connections between art and life. Then she adds:

If an artist is chosen to be the protagonist of a play or novel, that choice naturally leads to the thematization of questions and dilemmas about the existence of art and the artist; relations between art and life, art/artist and the world; the nature of artistic creation; differences between ways of life, values, and views of ordinary people and artists; relations between individual and community, between the subject and objective reality; and many other similar issues.

No doubt, however, with the advent of highly sophisticated and challenging notions such as formalism and the death of the author, it is hard to conceive the dilemma of the artist without paying attention to the interrelations between art and life in which the ideal and reality, subject and object, constitute sharp contrasts. Accordingly, one of the most pressing dilemmas of the artist is social: How can the artist function as a member of a certain community and at the same time retain the distinctiveness of his role as an outsider whose social usefulness is based on his chronic estrangement from the ordinary concerns of society? By this, I mean the perplexing dilemma in which the artist finds himself/herself as he/she struggles to reconcile private desire with public expectation.

The Kantian cult of "art for art's sake"1 has represented the source of debate concerning the role and function of the artist in society. According to this paradigm, works of art "exist primarily to satisfy the needs of art"( Gaztambide-Fernandez, 2008, p. 242). The supporters of this approach look at art as something enclosing itself in its famous ivory tower.

In his book, Aesthetics and Politics (1997, p. 178) Adorno said 'art for art's sake' denies by its absolute claims that ineradicable connection with reality which is polemical a priori of the attempt to make art autonomous from the real. Between these two poles the tension in which art has lived in every age till now is dissolved." [Adorno's italics]

As mentioned before, the relationship between art and life is polemical. It is true that under the banner of "art for art's sake", the artist is responsible only to his work, yet he cannot ignore human life. In an article entitled "The Responsibility of the Artist," Maritain (1960) argues "to assume that it does not matter what one writes is permissible only to the insane; the artist is responsible to the good of human life, in himself and in his fellow men." Thus,

${ }^{1}$ For an elaborate discussion of this concept in aesthetic theory and its history, see Richardson, 1944, pp. 243-260. 
his dilemma originates from confronting the inevitable tension between moral responsibility to life and aesthetics.

Although the formalists did not fully cling to the idea of autonomy, they did not reject it. They asserted the independence of art from any social, economic and historical facts. For Shklovsky, (cited in Trotsky, 1968) art "was always free from life." Unlike most Marxists who believe in the work of art as a record of social reality that "needs not only to be recognized but also to be understood," Trotsky affirms on the relative autonomy of art. In Literature and Revolution, he insists that "art must be judged in the first place by its own autonomous laws- that artistic creation is a 'deflection, a changing and a transformation of reality, in accordance with the peculiar laws of art."' (Ibid, p. 175) This formulation, which is in part from the Russian formalist theory that art engages a "making strange" of experience as Eagleton has shown (1976, p. 51), modifies Trotsky's notion of art as reflection. In this regard, he looks at art as a powerful means to destroy barriers and shape social reality. It is not a mere mirror.

Trotsky (cited by Slaughter, 1980, p. 112) argues that:

Of course no one speaks about an exact mirror. No one even thinks of asking the new literature to have a mirror-like impassivity. The deeper literature is, and the more it is imbued with the desire to shape life, the more significantly and dynamically it will be able to 'picture' life.

As far as reflection is concerned, Brecht gives it due attention. In his " $A$ Short Organum for the Theatre," (ed. by Willett, 1986, p. 204) Brecht maintained that "if art reflects life it does so with special mirrors. Art does not become unrealistic by changing the proportions." By saying this, Brecht denies the corresponding relation between social reality and representation for producing a work of art. So breaking the mirror or "changing the proportion" does not mean that the work of art is not realistic. On the contrary, it will "heighten it."(Ibid.)

In accounting for the role of the artist and art in real life, Sartre (1978, p. 18) insists on the social responsibility of the artist and the intellectual in general. This is quite clear in his rejection of "art for art's sake." Today the writer "should in no case occupy himself with temporal affairs. Neither should he set up lines without meaning nor seek solely beauty of phrase and imagery." For Sartre, the artwork always carries a special power which found expression in communicating among freedoms without alienation or objectification. It is one side of art's spontaneity. In this sense, the relation between artist and public is intimate and reciprocal. The work of art is a mediator between them. Some writers go further to declare that the artist is no longer solely responsible for the production of a literary work. In other words, the work of art does not gain its significance without the impression of the audience. What is important, as Page said, "is not who the author is, but what he or she wrote. The author may therefore create a consistent persona in their work which can be inferred from 
discourse, but this does not necessarily imply that he or she can determine exactly how the persona is interpreted" (Page, 1992, p. 20).

This leads us to another aspect of art which "serves the public world of human responsibility, not the narrow, private world of art for art's sake," to use Fricke's words (Fricke, 1973, p. 220). What is needed here is a kind of equilibrium between aesthetic and immediate needs of the society. In an article entitled "Dilemma of the Contemporary African Artist" H. Ato Delaquis (1976, pp. 20-23), rightly said that art should be "inspired by the present environment" of the society. Despite its great aesthetic appeal, art "cannot be divorced from the spiritual aspirations of the community." Thus, the artist expresses the social enigma of social life without neglecting aesthetic qualities in his work. In doing so, his dilemma lies in finding a form of expression to distinguish beauty from ugliness to the public's face. In this regard, the social responsibility of the artist is not only to improve the public's taste but also to reflect reality. The artist then "acts upon the taste of the public [and] his audience is a field where the fruits of his art ripen" (Richards, 1966, p. 221). The society becomes his realm to talk about. It is needless to say that its effects on the mentality of the artist cannot be denied. Therefore, instead of remaining enclosed in his ivory tower, the artist feels obliged morally to think of human beings. This moral obligation depends on his inner constraint which makes him firmly bind to the society.

\section{Art, Politics and Commitment}

In addition to the importance of art on social life, the significance of the writer's active involvement in politics had had a considerable impact on the notion of "commitment". However, the relationship between politics and art found expression in the belief that art has a decisive role in advancing and effecting change. In his speech about aesthetic autonomy within political commitment, Eagleton argues that art, as a radical thought is "conveniently sequestered from all other social practices, to become an isolated enclave within which the dominant social order can find an idealized refuge from its own actual values of competitiveness, exploitation and material possessiveness" (Eagleton, 1990, p. 9). But at the same time he does not deny its function as a revolutionary means of change. The concept of autonomy, to quote Eagleton:

is radically double-edged: if on the one hand it provides a central constituent of bourgeois ideology, it also marks an emphasis on the self-determing nature of human powers and capacities which becomes, in the work of Karl Marx and others, the anthropological foundation of a revolutionary opposition to bourgeois utility, (Ibid.)

Seen in this light, I find that it is apt to concentrate on the concept of "commitment" since it acquires so many debates among thinkers and writers. 
It, in turn, has a close relation to the role of the artist and art in society. In aesthetic theory, it is claimed by Adorno (1997, p. 180) that "commitment" should be distinguished from "tendency." Committed art in the proper sense is not intended to "generate ameliorative measure, legislative acts or practical institutions... but to work at the level of fundamental attitudes." Here, every commitment to the world must be abandoned to meet the ideal of the committed work of art. In his study of "The Author as Producer" (cited by Eagleton, 1976, p. 62; Benjamin, 1973, pp. 85-103), Benjamin insists that "commitment" is expressed in one's art not only by presenting correct political opinions but also " it reveals itself in how far the artist reconstructs the artistic forms at his disposal, turning authors, readers and spectators into collaborators."

The issue of political commitment is made more complicated in Trevor Griffiths's extensive interest in dramatizing political issues. This case, in turn reveals the artist's dilemma in one way or another. To be committed only to political issues or particular politics, other social issues would be ignored. In such a way, the moral responsibility of the artist towards society would be demolished. Griffiths has spoken in detail about the dilemma he has confronted in his personal life in trying "to reconcile his left-wing politics with his seemingly bourgeois professional career" (Quigley, 1993, p. 244). It has shown that the risk of conflict between political and aesthetic criteria cannot be easily avoided. This kind of conflict is repeatedly explored in Griffiths's plays such as Occupations (1970), Sam Sam (1972), The Party (1973) and All Good Men (1974).

However, to be devoted to one class at the expense of the other, the creation of enduring works of theatrical art becomes problematic in nature. Thus, they would not be a true reflection of society in its entire spectrum. In such a context, Griffiths said, "I don't feel proud of the fact that I got enjoyment out of writing for the [British] theatre and yet I can't lock into what is particularly efficacious about it. And I don't at all because I'm Northern, working-class and puritan by origin anyway, and developed to some extent, I feel rather guilty...."(Ibid) So he justifies his writing for television because television is the medium of the masses unlike theatre which is exclusive to the middle and upper classes. Consequently, a large segment of the population would be encompassed in developing important political and economic awareness about the nature of society. In such respect, Alvin Toffler (cited in Duncan, 1977, p. 73) admirably states that "the arts cannot thrive unless they are organically related to the needs of the surrounding society, unless the arts reach out far beyond their traditional audiences...." In doing so, the social factors should be fused with aesthetic elements in the artist's committed works. The artist as a human being could not separate himself from the society where he lives. He is the spokesman of humanity.

In what follows I shall consider the role of British theatre in reflecting the dilemma of the artist and his commitment in society. Because of several factors, not least amongst them its validity and relevance, theatre has been seen as a miniature of real life wherein the subject and object meet face to face. In 
one sense, theatre "can benefit from its ability to visually or audibly introduce works of art" (Bertha, 2009, p. 347). Then, through raising intriguing questions of representation of real life, the actor on stage will contribute to increasing the self-reflexivity of art. In doing so, the artist's human and artistic dilemmas expressed in the dialogues and monologues of the main characters "are not simply illustrated or reinforced through the visibility of the artworks, but... multiplying the layers of meaning." (Ibid., p. 365)

Therefore, art's functions such as aesthetic, ethical, psychological, social, and religious, will work either directly through the figure and the plight of the fictional artist or indirectly, through the effect of art on characters. In either case, the experience of the audience will be enriched and doubled through the self-reflexivity of the artist on stage. Unlike other genres of literature, drama represents the meeting-place of art and life. On the one hand, in theatre, art has a very limited lifespan. But on the other, time plays a significant role in the dramatic action. As soon as the play is over, it is gone forever. The only thing that remains is the impact in the hearts of spectators. Although the role of the artist as the ancient shaman who performed the healing of the community has vanished in this age of militant nihilism, nevertheless, he can still show partial "images of wholeness in the theatre" (Bertha, 2009, p. 364).

\section{The Representation of the Dilemma of the Artist in Contemporary British Theatre}

Looking back to British theatre since the late 1950s, we see that the seeds of change had already been planted. As Brassell (1985) has noted,"since the advent of the English Stage Company and the arrival of Osborne, our theatre, if not transformed, has been remarkably rejuvenated." He added:

British playwrights have advanced on several fronts: taking a more direct approach to social and political issues; bringing the language of their characters much closer to ordinary speech... Above all, perhaps, in reaching new audiences through the work of the 'fringe' and community theatre groups which have sprouted up across the country. (Brassell, 1985, p. 25)

In Modern British Playwriting: The 1970s, Chris Megson's (2012, p.34) quotation on theatre in 1970s reads: "If the Sixties were a wild weekend and the Eighties a hectic day at the office, the Seventies were a long Sunday evening in winter, with cold leftovers for supper and a power cut expected at any moment." This picture draws our attention to the development of contemporary British theatre since the fifties as we shall see later.

As mentioned before, the unremitting gloom which is described by Francis Wheen's view of the 1970s found expression in the social and political phenomena of Britain at that time. Among those phenomena are "a formidable economic downturn; unemployment and inflation."(Ibid.) Although this 
situation threw its shadow on different walks of life, theatre seemed far beyond reach.

Unlike Mainland Europe in the swaying whirlpool of Sixties which has witnessed riots and student protests, Britain increased the state subsidies for arts. Consequently, this action has led to the theatrical expansion in regional and alternative theatres. Megson points out that:

There were two events in the late 1960s that contributed to the exponential growth in alternative theatre at the start of the new decade. First, the Theatre Act (1968) abolished the state censorship of theatre and removed the powers invested in the Lord Chamberlain to license plays for performance....Second, there was a large expansion in public subsidy for theatre at the end of the 1960s. (Megson, 2012, p. 37)

This paved the way, then, for more freedom in discussing issues with topical and satirical content which had previously been restricted. Far from "only the most timidly naturalistic plays," the British stage was now free to present plays with new theatrical discourses and non-naturalistic settings as Phillips (2002) has asserted.

Aside from social realism, the "epic" and "agit-prop"1 plays stimulated their audiences to become involved in political activism. This is achieved in a broad range of styles and images which discussed contemporary concerns. David Edgar has stated that:

Most of the new playwrights of the 1970s came into the theatre at a time when there was a consensus between play-makers and their audiences that British society was rotten at the root, and that it was the proper business of the theatre to anatomise its rottenness and point the way to radical change. (Brassell, 1985, p. 30)

In the same vein, Bruce Birchall, playwright and artistic director argues that:

The post-1968 break-away movement became absorbed into the theatrical mainstream by state funding, and [...] what had begun as a piece of political practice ended up as a job, with the result that cultural workers began to see themselves as "left-wing artists", rather than as socialists who used art forms for political ends.

(Quoted in Megson, 2012, p.59)

Politically speaking, British theatre has basically split into two camps. On one level, it presented a politically-active, left-leaning vision that change can

\footnotetext{
1،Agitprop' -which is a combination of the words 'agitation' and 'propaganda' - means "a form of touring left-wing theatre intended to mobilise working-class audiences, especially at times of industrial struggle." Chris Megson, Modern British Playwrighting: The 1970s, p.44.
} 
be achieved via logic and reason. On the other level, some had a pessimistic view of life in which there was no place for logic and reason. This feeling has resulted from the disastrous outcomes of the two world wars.

With this in mind, Barker provides a significant contribution to the argument about the role of theatre in changing society. He also shows the relationship between the artist and his external environment. Barker, in Arguments for a Theatre (1989, p. 11) reveals his idea about the artist and theatre, arguing that in an age of populism, "the progressive artist is the artist who is not afraid of silence." An artist, he said, uses "imagination to speculate about life as it is lived, and proposes, consciously or unconsciously, life as it might be lived."(Ibid., p. 33)

In his speech about theatre, Barker affirms that the great responsibility of the actor is to attract the audience by showing them the unknown life that exists beyond the text. In other words, the writer and the actor conspire to entice the mind into a deeper analysis of what has been observed.

In his theory of the "Theatre of Catastrophe," Barker (Ibid., p. 54) points out that, like the tragic theatre, my theatre insists on the limits of tolerance as its territory. It "has never aimed for solidarity but to address the soul where it feels its difference." Barker, here wants theatre to be an efficient means of testing existent principles for making new ones. In such kind of theatre, the function of the dramatist is to show the ordeal of the audience in a language which exposes the entire range of human emotions and experiences (Ibid., p. 27).

It is certainly interesting to note here that art is a double-edged weapon. It may be positive and negative respectively. On the positive side, art is necessary in life especially when it is put at the service of human beings without constraints. The negative side of art is when it is used as propaganda for false ideology. Then, art will be a mere means to espouse a particular ideological viewpoint. This reflects the totalitarian claim that the artist "must be completely subservient" (Maritain, 1960, p. 1) and controlled by the state. In such an uncomprising reality, artists have no free will. They are dictated by and enforced to follow particular rules, legislated by the state itself. As Hitler's and Stalin's regime have shown, creative activities are accountable to the existing regime. Accordingly, the artists have a moral obligation towards politics which reveals their submissive nature to the state. Even their creativity should comply with aesthetic tenets set forth by the state "which claims to express and protect the needs of the people." (Ibid., p. 6)

A second dilemma of the artist is economic: How can an artist practice his art? This dilemma has two facets. On the one hand, it is related to subsidy the art received from public budget. On the other, it is the materialistic norms of the society in which the artist has immersed himself. Indeed, the dilemma that faces radical artists nowadays is that the popular forms of communication are often controlled by conventional and commercial forces at work in society. The materialistic side of the society has a negative impact on the artist in a way that inhibits his creative activity since his aim of writing would be secular. As a result, the art world would be corrupted by the market's inflated prices and by 
the dream artists. The market has taken the edge off the art world. The art world would be guided by the investors. The consequence of that is even art "which starts as a critique of society becomes depoliticized, objectified, institutionalized," consumed by those who have money as Becker has stated (1990, p. 16). Here, we have a problem posed for the artist from the outside. In this regard, Eliot (Fricke, 1973, p. 220) makes a distinction between two types of artists. The first one is the dedicated artist who devotes his effort to create beauty within the realm of social and moral responsibility. The second is the self-absorbed artist who uses art either as a means for financial gain or as a means to escape or reject duty and responsibility in the real world of human problems. In both cases, he will lose his function as a true artist.

The second aspect of the dilemma is concerned with the public subsidy of the arts. It is true that in an economic inquiry, the artists cannot be expected to pursue a large range of social changes in society. The arts are always in need for outside support if they are to continue to exist. Therefore, subsidy is important for the arts to be sustained. But the problem lies in the fact that to depend entirely on public subsidy, art will lend itself to the establishment as a means through which the establishment markets its policies. And through that process it takes away from the real situation of the human being. The artist, in turn would be a mere propagandist. As far as British theatre is concerned, debates about theatre and subsidy take two directions which clearly reveals people's attitude towards art. Many people felt that it was wrong for taxpayers' money to go to those who are against "the political status quo; young people should not be paid to bite the hand that fed them" (Wandor, 1993, p. 3). Here theatre is politicized to achieve particular aims far from the immediate needs of society. Others believed that a healthy and vigorous theatre is the one which reflects all shades of opinion as well as preserving all aesthetic forms, "and those in receipt of subsidy should not be discriminated against on the grounds of their politics" (Ibid)

In her book Stages in the Revolution, Itzin has talked about the political theatre in Britain and the difficulties surrounding it (Itzin, 1982, p. 95). The theatre, whether it is conventional or commercial has been the domain of the bourgeoisie. The economic and cultural system were in their hands. So, if the political playwright, to quote David Mercer, "does not write for the bourgeoisie... [his] plays cannot be seen" because the bourgeoisie owns the means of production without which no play comes into existence. The domination and hegemony of the bourgeoisie on the one hand and his duty towards his natural allies, the working class on the other, has led the dramatist to feel bewildered and virtually untenable.

However, it is not only money which is the source of the artist's economic dilemma but rather the existence or the paucity of good audiences. In other words, how can art stimulate "publics in adequate numbers with appetites for excellence and authenticity [and at the same time] provide the social setting in which art can thrive?" (Feldman, 1962, p. 5). Although at times the economic predicament seems immediate, subsidy is not the serious problem. Nowadays, art can be subsidised by different veins such as local and federal governments, 
foundations, universities, corporations and even some communities. In such rapid industrialization and the development of science and technology, the real problem of the artist is to find "enough interested people [who are willing] to give their time to art" (Ibid, p. 6). Under such perilous circumstances, the artist's genuine dilemma lies in confronting the Zeitgeist, the general intellectual and moral tendencies of an era, which can be evasive and intangible.

In addition, the appearance of modern means of communication, represented by television and cinema, was one of the challenges for the role of the British theatre and people's reception in real life. Although this is to a certain degree true, theatre still remains a magical place. In his answer to the question about the role of British theatre to attract people in comparison with the cinema and television, David Edgar (1993, p. 458) states that what makes theatre different, "is the play of the imagination in the presence of the event in front of you." In the theatre, the audience is put into the picture spontaneously. The event, which is being witnessed collectively, gives an opportunity for people to share opinions and views. The theatre has the capacity as a medium to engage its audience in a live conversation.

However, the dilemma of the artist in contemporary British theatre passes through many stages as it develops. The main developments in British theatre following John Osborne's Look Back in Anger (1956) at the Royal Court Theatre ushered in a new period of important playwriting. The great subject of the post-1956 British theatre was the limits of the democratization of British society during the war. The first wave of new playwrights, from John Osborne and Arnold Wesker to the early Edward Bond is to "confront the cultural consequences of working class empowerment" (Ibid, p. 456).

If we take a historical glance at British theatre after the 1960s, we see that British theatre has reached its fulfillment. The social and political changes, together with the technological advances have left their imprint on British theatre. Motivated by new ideologies, from Marxism to feminism, playwrights take on their shoulders the task of political and cultural change. Their efforts were crowned by the founding of the National Theatre and the abolition of state censorship of theatre in 1968. Having realized the importance of theatre in life, questions have been raised "about the function of drama, the nature of its reception and the relationship between form and content" (Innes, 1992, p. 1).

From the 1970s onwards, a whole new phase of British theatre seemed to begin. The British theatre has changed in many respects:

...numbers and kinds of venues; a variety of approaches to the making of drama; attitudes to public subsidy; searches for new audiences; enthusiastic playwrights, especially the new cultural voices of women and ethnic writers; realism and politics; above all the agenda... which debates the relationship of the individual to his/her society. (Wandor, 1993, p.1) 
The political and cultural conditions which gave rise to the flowering of British theatre could not come into existence without the figure of Jenny Lee, Britain's first Minister for the Arts. Through her policy of public funding to attract new audiences for the arts and to encourage young practitioners, more than 100 theatre venues were built in the mid-1960s (Wandor, 1993, p.2.).

As far as theatre is concerned, funding increased steadily to match the demands of a variety of new work. Government financial aids increased, not only to the principal companies but also to an increasing number of 'fringe' or alternative theater ${ }^{1}$ as they appeared in the late 1960s. So, theatre became a powerful attraction for the new young writers and "those interested in propagating social theories," as Bigsby (1981) has pointed out.

However, the period from 1968 to the mid-1970s witnessed the rise of a politically committed theatre. The major thrust of contemporary British theatre is overtly political. Thus, a great deal of "agit-prop" plays (agitationpropaganda) emerged. In one sense, they reflected the function of theatre and playwrights during that time.

If we take Piscator's views of political theatre, we shall get an accurate summary of British left-wing drama in this period. For Piscator (1978, p. 47), the function of the writer is primarily political. He must put his own ideas aside and devote himself to bring out "the ideas which are alive in the psyche of the masses." Theatre always responds, more directly and abruptly to the present moment by conveying messages. For him "man portrayed on the stage is significant as a social function" (Ibid.). In an agreement with John Arden, he asserts that "Man is not made into a political animal by political theatre, however, but by a social world which ineluctably charges him with political significance" (Ibid., p. 36). He adds:

We, as revolutionary Marxists, cannot consider our task complete if we produce an uncritical copy of reality, conceiving the theatre as a mirror of the time. We can no more consider this our task than we can overcome the state of affairs by theatrical means alone, nor can we conceal the disharmony with a discrete veil, nor can we present man as a creature of sublime greatness in times which in fact socially distort-in a word, it is not our business to produce an idealistic effect. The business of revolutionary theatre is to take reality as its point of departure and to magnify the social discrepancy, making it an element of our indictment, our revolt, our new order.

(Piscator, 1978, p. 37)

\footnotetext{
${ }^{1}$ The "alternative" theatre democratised the social division in the theatre by initiating flexible and collaborative work methods. It proposes an alternative to the way of theatre organization, production and distribution. In this theatre, new audiences are introduced by "representing the experiences and interests of groups of oppressed and exploited people whose lives and emotions and hopes they felt had not been adequately represented on the mainstream stage" (Wandor, 1993, p. 13; see also Allan, 1981).
} 
But Piscator's theatre was subject to the same problems which afflicted contemporary British drama. This problem can be summed up in the matter of government subsidy. Within this, there is a profound debate about the function and morality of art itself. The writer "fears that he may be an accomplice to a process of manipulation which is perceived in the external world, but which invades an art which no longer has the autonomy proposed by modernist aesthetics" (Ibid, p. 22). It certainly focuses on the dilemma of the playwright who, on the one hand seeks directness without restrictions, and on the other, formal experiment. However, the affinity between political commitment and aesthetic experimentation has always proved difficult.

Therefore, the function of the playwrights is determined by the state which is responsible for theatre subsidy. Conversely, a radical drama is "being subsidized by the state it wishes to destroy" (Piscator, 1978, p. 22). As a leftdrama in Britain, it inevitably associates itself with its enemy. As a result, it has attested to its apparent lack of confidence in its ability to effect change. The playwright cannot exceed the role assigned to him. David Hare is quoted in the National Theatre program for A Map of the World (Buckroyd, 1986, p. 51) as having said "As a playwright, I can't offer a solution to the world's problems. What I can do is [just] make people think about them." Most writers are constrained by a particular point of view which does not necessarily reflect their own. In this context, theatre as a highly visible and social practice makes clear the consequences of state interference in a way that no literary or visual arts do.

It is worth noting that one of the reasons for the absence of women playwrights during 1960s was ascribed to the cultural climate of British society. C. W. E. Bigsby (1981, p. 16) suggests that "women avoid drama as a social art requiring the strength and personal acerbity necessary for sustaining one's views in a public arena." The playwright has to battle with producer, director and actors for his plays to see the light.

Because of the world recession in the mid-1970s, provoked by the oil crisis, Britain underwent economic ruin. It was the British "Winter of discontent" as it was called in 1978 which culminated in a period of acute industrial strife (Kershaw, 1999, p. 171). This situation cast its shades on different aspects of life. Theatre was not an exception. Accordingly, by the second half of the 1970s, the Arts Council "sought to rationalize and relocate responsibility for funding" (Wandor, 1993, p. 3). So, debates emerged concerning the amount of money earmarked for theatre. In doing so, theatre is discriminated according to particular "standards" which determine the levels of state subsidy. One explanation for this action is that theatre is seen as a place of investment. It is in turn subject to market forces.

This paved the way for more decadence in British theatre with Margaret Thatcher's general election in 1979. In Thatcherism's period, the market was seen as "the sole motor of arts development." Under its discipline, the producers of art found themselves forced to "provide what its consumers wanted" (Edgar, 1999, p. 14). 
In his book, State of Play: Playwrights on Playwriting, Edgar expounds that the new spirit that had entered and sought to dominate the British theatre was no longer political emancipation but "economic liberalism" (Ibid., p.10). The art theatres were commercialized.

In her encouragement of the culture of enterprise and free-markets economics, Thatcher seeds the feeling of competition which was hostile to innovation. In justifying for this new policy, Mrs Thatcher's first Arts Minister Norman St John Stevas defends, saying "private funding not only provide ' an alternative source of finance' but also had the merit of ' avoiding or neutralizing some of the dangers of state patronage, such as censorship and conformity and the promotion of what I might venture to call "establishment art" (Edgar, 1993, p. 453).

The modernist liberal view of the artist as a human being who offers society works which go beyond any particular political and economic regime died with the coming of the Conservative Party under Margaret Thatcher who was suspicious of "intellectuals", as she called them. She thought they talked more than they acted. Consequently, her policy in decreasing state funding for the arts continued (Evans, 2004, p. 141). Keeping in mind the fact that British theatre had relied heavily on state support to survive since the 1960s, it struck at the core of Thatcher's policy. Theatre is affected not only by restricting the number of productions that could be staged, but also the type of plays that it could afford to stage. So many artists resented and felt an urgent need to respond against the government's attitude to arts funding.

In the early 1980s, British subsidy for theatre was subjected to a fundamental shift in the ideology and economics of the funding decisions which "revolutionized its relationships to the public sphere" (Kershaw, 1999, p. 271). It was clear that the market played a decisive role not only in society but also in peoples' attitudes towards life. This was a time when everything was purely measured by monetary factors. Here, the dilemma of the playwright was to find a suitable subject to address his audience who lived in a culture of new selfish money-making ethic.

Perhaps one less-visible phenomenon of the 1980s was the rise in the movement of self-help and education playwrights which came about as a direct response to the reduction in state support for art. The other prominent phenomena were the active role of women playwrights. In the eighties, most of the plays, presented at the Royal Court were by women (Edgar, 1993, p. 454). They developed an examination of the internal worlds of social issues which were caused by Thatcher's philosophy. In this connection, Caryl Churchill's Top Girls (1982) and Serious Money (1987) are critical of Thatcherism.

The writers who emerged in the 1990s had experienced the ebbing and flowing of Thatcherism. They has been brought up with "the belief that profit was the ultimate test of anything's worth" (Billington et al, 2004, p. 89) which they repudiated completely when they started writing.

In the 2000s, there is a new approach in British theatre which makes it unique. One of the developments is that theatre is run by artistic directors who are in immediate contact with the dilemmas that the playwrights suffer from. 
The second thing is that theatre manifests its ability "to respond quickly to current events, much more so than television and cinema" (Ibid, p. 93). It, in turn reveals the theatre's function to reflect reality. A good example of how theatre responded is a series of early evening staged forums by the Royal Court on the Iraq War. More interestingly, are the debates waged among different writers. In this concern, Martin Crimp wrote a wonderful satire called Advice to Iraqi Mothers (2003). Likewise, Caryl Churchill did a factual piece, Iraqdoc, which relied on exchanges between Iraqis and Americans online in chartroom.

The dilemma of the artist, as this study will strive to show, is the playwright's attempts to be true to his art. The playwrights such as Stoppard, Barker, Brenton, Wertenbaker and Crimp are preoccupied not only with presenting those dilemmas but in finding a common ground between art and life. Their transcendent end is to convey the truth to audience.

\section{References}

Adorno, T., 1997. Commitment. In: R. Taylor, ed. Aesthetics and Politics. London: Verso.

Allan, J., 1981. Theatre in Europe. Eastbourne.

Barker, H., 1989. Arguments for a Theatre. London: John Calder.

Becker, C., 1990. Social Responsibility and the Place of the Artist in Society. Chicago: Lake View Press.

Benjamin, W., 1973. Understanding Brecht. Translated from German by A. Bostock. London: New Left Books.

Bertha, C., 2009. Visual Art and Artist in Contemporary Irish Drama. Journal of English and American Studies (HJEAS), 15(2).

Bigsby, C.W.E., ed., 1981. Contemporary English Drama. London: Edward Arnold (Publishers) Ltd.

Billington, M. et al., 2004. The State of British Theatre Now: An Interview with Michael Billington. Atlantis, 26(1).

Brassell, T., 1985. Stoppard: An Assessment. London: The Macmillan Press Ltd.

Buckroyd, P., 1986. British Drama 1975-1985. Rocky Mountain Review of Language and Literature, 40(1/2).

Delaquis, H.A., 1976. Dilemma of the Contemporary African Artist. Transition, 50.

Duncan, E.H., 1977. The Artist in Contemporary Society: Report of an International Symposium. Leonardo, 10(1).

Eagleton, T., 1976. Marxism and Literary Criticism. London: Methuen.

Eagleton, T., 1990. The Ideology of the Aesthetic. UK: Blackwell.

Edgar, D., 1993. State of Play: New Work in the contemporary British theatre. RSA Journal, 141(5440).

Edgar, D., 1999. State of Play: Playwrights on Playwriting. London: Faber and Faber. Evans, E.J., 2004. Thatcher and Thatcherism. $2^{\text {nd }}$ edition. London: Routledge.

Feldman, E.B., 1962. Dilemma of the Artist. Studies in Art Education, 4(1).

Fricke, D.C., 1973. Art and Artists in "Daniel Deronda". Studies in the Novel, 5(2).

Gaztambide-Fernandez, R.A., 2008. The Artist in Society: Understanding, Expectations, and Curriculum Implications. Curriculum Inquiry, 38(3).

Innes, C., 1992. Modern British Drama 1890-1990. Cambridge: Cambridge University Press. 
Itzin, C., 1982. Stages in the Revolution: Political Theatre in Britain since 1968. London: Methuen.

Kershaw, B., 1999. Discouraging Democracy: British Theatres and Economics, 19791999. Theatre Journal, 51(3).

Maritain, J., 1960. The Responsibility of the Artist. Princeton: University of Princeton, N.J. Available also from: http://maritain.nd.edu/jmc/etext/resart1.htm (Accessed December 09, 2013).

Megson, C., 2012. Modern British Playwrighting: The 1970s. London: Methuen Drama.

Page, A., 1992. Introduction: The Death of the Playwright? In: Modern British Drama and Literary Theory. London: The Macmillan Press LTD.

Phillips, T., 2002. Fifty Years of British Theatre. Contemporary Review, 281(1639), August 2002. Available also from: www documents <http: www.findarticles.com/p.articles/mi_m2242/is_1639_281/ai_91210883> (Accessed 11 February 2015)

Piscator, E., 1978. The Political Theatre: A History 1914-1929. Translated by H. Rorrison. New York.

Quigley, A.E., 1993. Creativity and Commitment in Trevor Griffiths's Comedians. In: H. Zeifman \& C. Zimmerman, eds. Contemporary British Drama 1970-90. Toronto: University of Toronto Press.

Richards, H., 1966. The Social Responsibility of the Artist. Ethics, 76(3).

Richardson, D., 1944. Saintsbury and Art for Art's Sake in England. PMLA, 59(1).

Sartre, J.-P., 1978. What is Literature? Translated from French by B. Frechtman. London: Routledge.

Slaughter, C., 1980. Marxism, Ideology and Literature. London: The Macmillan Press LTD.

Trotsky, L., 1968. Literature and Revolution. Ann Arbor: The University of Michigan.

Wandor, M., 1993. Drama Today: A Critical Guide to British Drama 1970-1990. London: The British Council.

Willett, J., ed. 1986. Brecht on Theatre. London: Methuen. 
